\title{
Effects of irrigation and collection period on grapevine leaf (Vitis vinifera L. var. Touriga Nacional): Evaluation of the phytochemical composition and antioxidant properties
}

\author{
David Barreales $^{\mathrm{a}, \mathrm{b}, *}$, Ricardo Malheiro ${ }^{\mathrm{a}}$, José Alberto Pereira ${ }^{\mathrm{a}}$, João Verdial ${ }^{\mathrm{a}}$, Albino Bento ${ }^{\mathrm{a}}$, \\ Pedro Antonio Casquero ${ }^{c}$, António Castro Ribeiro ${ }^{\mathrm{a}}$ \\ ${ }^{a}$ Centro de Investigação de Montanha (CIMO)/Escola Superior Agrária, Instituto Politécnico de Bragança, Campus de Santa Apolónia, 5300-253, Bragança, Portugal \\ b Department of Engineering and Agricultural Sciences, Universidad de León, Av. Portugal 41, 24071, León, Spain \\ ${ }^{\mathrm{c}}$ Research Group of Engineering and Sustainable Agriculture, Natural Resources Institute, Department of Engineering and Agricultural sciences, Universidad de León, Av. \\ Portugal 41, 24071, León, Spain
}

A R T I C L E I N F O

\section{Keywords:}

Leaves

Deficit irrigation

Vitis vinifera $\mathrm{L}$.

Total antioxidant capacity

\begin{abstract}
A B S T R A C T
The cultivation of grapevines (Vitis vinifera L.) has extended worldwide, with great economic importance. From this crop, we can obtain grapes for fresh consumption, raisins, juices, wine, and other derived products. The cultivation of grapevines also generates some byproducts, such as seeds, skins, wood and leaves. The leaves can be removed from the plant, as is common agricultural practice, to improve the production and quality of the grapes at certain periods in the crop cycle. In the present work, the phytochemical composition (total phenols content, hydroxycinnamic acids derivatives and flavonols) and antioxidant potential (reducing power, ABTS and DPPH radical scavenging capacity) of grapevine leaves from cv. Touriga Nacional were evaluated. The studied cultivar was under three severities of regulated deficit irrigation (RDI60, RDI40, and RDI20; providing 60, 40 and $20 \%$ of reference evapotranspiration, respectively) and non-irrigation (NI; exclusively rain-fed), in a vineyard located in the Demarcated Douro Region (Portugal). The leaves were collected at three different phenological stages: veraison, maturation, and grape harvest. For the first time, the interactions between different irrigation regimes and the collection period were evaluated on grapevine leaves. The results obtained for the phytochemical composition revealed that increasing irrigation reduced total phenols content, hydroxycinnamic acids derivatives, and flavonols in all of the phenological stages studied. For instance, compared to that of the control treatment (NI), the total phenols content reduced 19\% in RDI20 (from $189 \mathrm{mg} \mathrm{GAE} \mathrm{g}^{-1}$ to $153 \mathrm{mg} \mathrm{GAE}$ $\mathrm{g}^{-1}$ ), $28 \%$ in RDI40 (136 $\mathrm{mg} \mathrm{GAE}^{-1}$ ), and 33\% in RDI60 (127 $\mathrm{mg} \mathrm{GAE}^{-1}$ ). The antioxidant activity suffered a reduction when the irrigation amount was increased for all assays. Additionally, the antioxidant activity suffered a reduction over time, presenting higher values in veraison. For harvest sampling, the loss of antioxidant activity was more notable, with $\mathrm{EC}_{50}$ values varying between $0.092 \mathrm{mg} \mathrm{mL}^{-1}$ (NI) and $0.187 \mathrm{mg} \mathrm{mL}^{-1}$ (RDI60). Altogether, the results suggest that grapevine leaves are a potential source of natural compounds with valuable antioxidant properties that could be explored by the pharmaceutical, chemical and food industries.
\end{abstract}

\section{Introduction}

Drought is the main environmental factor limiting the production of quality grapes in most of the world's wine-producing regions (Jones, 2013). The Douro Demarcated Region in Portugal produces famous Port wines, as well as other types of wines, on a land area of 247,420 ha. Currently, the agricultural practices are changing in this region including the addition of irrigation systems to achieve acceptable grape yield and quality. Several studies have demonstrated the importance of irrigation in improving the grape yield and quality in areas with arid and semiarid climates (Kriedemann and Goodwin, 2003; De la Hera et al., 2004; Torres et al., 2017).

In recent years, the number of dry days per year has increased in southern Europe. In the future, almost all of the models predict a reduction in the precipitation in Portugal during the spring, summer, and autumn months. Jones (2013) predicts that, in all future scenarios the

\footnotetext{
* Corresponding author at: Centro de Investigação de Montanha (CIMO)/Escola Superior Agrária, Instituto Politécnico de Bragança, Campus de Santa Apolónia, 5300-253, Bragança, Portugal.

E-mail address: davidsantos@ipb.pt (D. Barreales).
} 
entire Douro Region will see a significant increase in the average temperatures up to 2080 .

Regulated deficit irrigation (RDI) is one of the most frequently used irrigation strategies in vineyards with the aim to balance grapevine vegetative and reproductive growth by applying less than the full vineyard water use at specific periods of the growing season (Dry et al., 2001). However, successful strategies may vary between regions with different climates and can even be site-specific, depending on the interactions within the grapevine variety, soil type and vineyard management practices (Romero et al., 2013). Irrigation programs are introduced in the vines to improve grape production for wine or table grape, never to improve the composition of leaf production.

The rich and varied chemical composition of $V$. vinifera leaves appears to contribute to their biological potential (Fernandes et al., 2013; Lima et al., 2016). Previous chemical investigations have shown the presence of several organic acids, phenolic acids, flavonols, tannins, procyanidins, anthocyanins, lipids, enzymes, vitamins, carotenoids, terpenes, and reducing or nonreducing sugars in grapevine leaves (Hebash et al., 1991; Şendoğdu et al., 2006; Xia et al., 2010; Doshi et al., 2006; Delìorman Orhan et al., 2009). In many countries of the Mediterranean Basin, the grapevine leaves are considered a delicacy, particularly in Greek cuisine, (Harb et al., 2015). Grapevine leaf infusion may be a potential alternative to take advantage of vineyards after a grape harvest. These findings have led to a considerable interest in grapevine leaves as a promising source of compounds with nutritional properties and biological potential (Lima et al., 2017; Devi and Singh, 2017). This approach also provides a means of taking advantage of this byproduct.

Normally, the grapevine leaves have no economic use in many producing countries and simply remain in the vineyard for incorporation into the soil as organic matter and for, in other cases, animal feed. Some agricultural practices carried out in the vineyard justify the periods selected to collect the grapevine leaves. In these periods, the vine leaves can be treated as a byproduct: in the phenological stage veraison and maturation. Leaf removal is the process of eliminating leaves from the vine in the area around the fruit clusters, usually immediately above and immediately below the fruit. This technique, also called leaf thinning, is usually applied in order to improve air circulation, increase fungicide/insecticide spray penetration, increase exposure of a cluster to sunlight and aid in the ripening process. Furthermore, leaf thinning improves the phenolic fraction in berries (Bubola et al., 2017; Pastore et al., 2017), which can lead to a high-quality wine. After grape harvest, it is also a good moment to take advantage of this byproduct, because the leaves stops being functional for the plant and, with the arrival of cold weather, begin the senescence phase.

There are many research studies that have measured the phytochemical composition and antioxidant activity of grapes, leaves and other parts of the vine but few that relate these parameters to RDI and phenological stages. Within the existing balance of the vine plant between the different organs parts, one can predict that high phytochemical content and bioactive properties in leaves can also lead to high levels in grapes and consequently in the produced wine (Hamman and Dami, 2000; Roby and Matthews, 2004).

In this sense, the main objective of the present study was to establish the antioxidant properties and phytochemical composition of grapevine leaves under RDI and at different harvestdates, corresponding to three phenological stages: veraison, maturation and grape harvest.

\section{Material and methods}

\subsection{Experimental site}

The trial was located in a commercial organic vineyard, located in the Douro region, NE Portugal (latitude $41^{\circ} 31^{\prime} \mathrm{N}$; longitude $7^{\circ} 5^{\prime} \mathrm{N}$; $326 \mathrm{~m}$ a. s. 1.). The selected cultivar was Touriga Nacional, an important traditional Portuguese variety. The vineyard was planted in 2008. Vine
Table 1

Dates of first and last irrigation and total water applied for the three treatments.

\begin{tabular}{|c|c|c|c|c|c|c|}
\hline \multirow[t]{2}{*}{ Growing season } & \multicolumn{2}{|c|}{ Irrigation dates } & \multicolumn{3}{|c|}{$\begin{array}{l}\text { Water applied } \\
(\mathrm{mm})\end{array}$} & \multirow{2}{*}{$\begin{array}{l}\text { Rainfall (mm) } \\
\text { NI }\end{array}$} \\
\hline & $\begin{array}{l}\text { First } \\
\text { irrigation }\end{array}$ & $\begin{array}{l}\text { Last } \\
\text { irrigation }\end{array}$ & RDI20 & RDI40 & RDI60 & \\
\hline 2014 & 25 Jun & $05 \mathrm{Sep}$ & 70.3 & 140.6 & 211.0 & 192.8 \\
\hline 2015 & $15 \mathrm{Jul}$ & $11 \mathrm{Sep}$ & 65.2 & 130.3 & 195.5 & 172.2 \\
\hline
\end{tabular}

spacing was $2.2 \times 1 \mathrm{~m}\left(4545\right.$ vines $\left.\mathrm{ha}^{-1}\right)$ and the vines were unilateral cordon trained and spur-pruned with vertical shoot-positioning. Vine rows were north-south oriented.

\subsection{Irrigation treatments and experimental design}

RDI was first applied to the vineyard in 2014 and it continued during the following year. The leaves for this study were collected during 2015. Irrigation water was applied three times a week, from preveraison until harvest, through a drip irrigation system (Table 1). The vines were irrigated at three severities of deficit irrigation: RDI60, RDI40 and RDI20, which provides 60,40 , and $20 \%$ of reference evapotranspiration $\left(\mathrm{ET}_{\mathrm{o}}\right)$, respectively, and non-irrigated (NI). The reference evapotranspiration was calculated using the modified FAO Penman-Monteith method (Allen et al., 1998). This method requires air temperature, air humidity, radiation, and wind speed data. Climatic data were automatically collected from a weather station located near the experimental trial.

The beginning of irrigation, in each year, was determined by grapevine water status. The - $0.4 \mathrm{MPa}$ value of predawn leaf water potential was established to start irrigation that was continuously carried out until harvest. The weekly volume of irrigation water to be applied was calculated each week according to the previous week's total ETo and effective precipitation using the following equation:

$\mathrm{RDI}=(\mathrm{K} \times \mathrm{ETo}-\mathrm{Pe}) / \mathrm{Er}$

Here Pe is the effective precipitation; Er is the irrigation efficiency of the irrigation system (0.95). The $\mathrm{K}$ value represents the fraction of the ETo for the different irrigation regimes ( 0.2 for RDI20; 0.4 for RDI40, and 0.6 for RDI60).

The experimental design was a randomized block with a one non irrigation and three irrigation treatments with four replicates. Irrigation treatments were randomly allocated to plots within each block and the same irrigation treatment was applied to a plot for each successive growing season.

The climate is classified as Mediterranean, according to Köppen classification (Köppen, 1923). Summers are hot and dry and winters have moderate temperatures and changeable, rainy weather. The climatic conditions have been measured during the two years of the experiment and are reported in from July to September 2015 (Fig. 1). The predawn leaf water potential was measured with a pressure chamber (Model 1000, PMS Instrument Company, Albany, USA). Measurements were made before sunrise.

\subsection{Plant material and phenological stages}

The influence of RDI on leaf composition of the Portuguese winegrape Touriga Nacional ( $V$. vinifera L.) was evaluated in three different collected moments. The leaves were collected in the second year (2015) of the field experiment, in three different dates, corresponding to three phenological stages: veraison $\left(11^{\text {th }}\right.$ August), maturation $\left(1^{\text {th }}\right.$ September) and grape harvest $\left(28^{\text {th }}\right.$ September). Further information regarding the phenological stages selected: $11^{\text {th }}$ August 2015 - "veraison", 81 from $\mathrm{BBCH}$ scale (beginning of ripening: berries begin to brighten in colour); $1^{\text {th }}$ September 2015 - "maturation", 83 from BBCH 

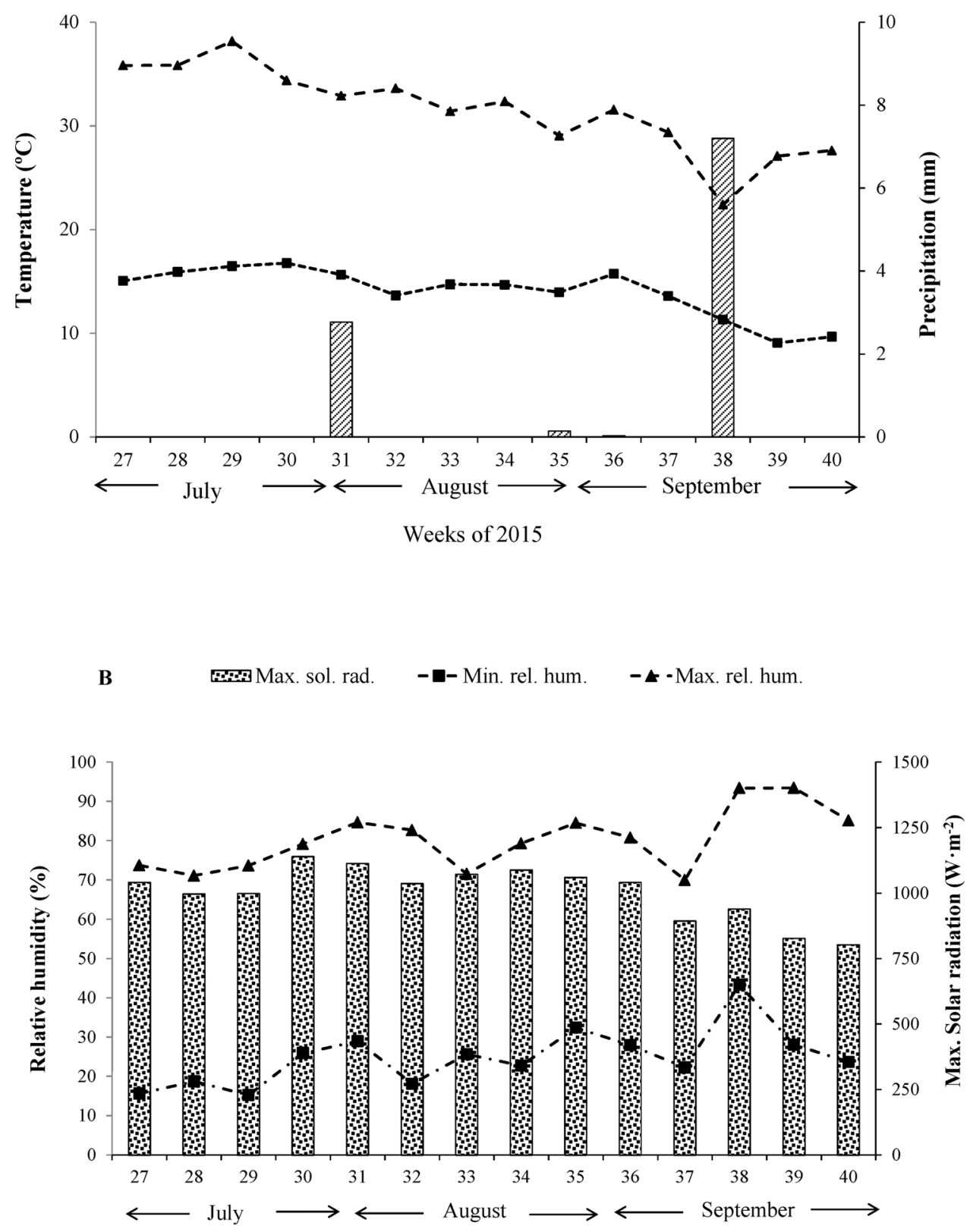

Weeks of 2015

Fig. 1. Climatic conditions during the months of July, August and September 2015. (A) Precipitation (mm), maximum and minimum temperatures $\left({ }^{\circ} \mathrm{C}\right.$ ); (B) Maximum and minimum relative humidity (\%), and maximum solar radiation $\left(\mathrm{W} \cdot \mathrm{m}^{-2}\right)$.

scale (berries developing colour); $28^{\text {th }}$ September 2015 - "harvest", 89 from BBCH scale (berries ripe for harvest). (Lorenz et al., 1995; Meier, 2001).

Four independent samples of approximately $250 \mathrm{~g}$ of leaves were collected on the intermediate zone of the adult shoot per irrigation treatment and collected moment. Once in laboratory, leaves were visually inspected and those with signs of pests and diseases as well as mechanical damages or with birds excrements were rejected for analysis, being all the debris removed and leaves cleaned when necessary with distilled water. Dust was removed with a slightly humidified scientific paper to avoid mechanical damages and cells disruption in the leaves. All samples were then frozen.

\subsection{Samples preparation and extraction conditions}

All samples were freeze-dried and then grinded. The aqueous extractions were performed according to Lima et al. (2016): $5 \mathrm{~g}$ of freezedried leaves were extracted with $250 \mathrm{~mL}$ boiling water during $45 \mathrm{~min}$, and then the extract was frozen, freeze-dried and dissolved in water to a final concentration of $50 \mathrm{mg} \mathrm{mL}^{-1}$. For each parameter assessed in this study, per extract, two replicates were performed.

\subsection{Determination of different groups of phenolic compounds}

The determination of total phenol content, hydroxycinnamic acid 
derivatives and flavonols was performed according to the methodology described by Boulanouar et al., (2013). One milliliter $\left(0.5 \mathrm{mg} \mathrm{mL}^{-1}\right.$ of extract) was diluted with $1 \mathrm{~mL}$ of aqueous ethanol $(95 \% \mathrm{v} / \mathrm{v})$ containing $0.1 \%$ of hydrochloric acid and $8 \mathrm{~mL}$ of $2 \%$ hydrochloric acid. The absorbance was measured at $280 \mathrm{~nm}$ to determine total phenols, at $320 \mathrm{~nm}$ to determine hydroxycinnamic acid derivatives, and at $360 \mathrm{~nm}$ to determine flavonols content (Genesys 10UV, Thermo Electron Corporation). The results were expressed as gallic acid equivalents (GAE) $\mathrm{g}^{-1}$ of extract for total phenols, caffeic acid equivalents (CAE) $\mathrm{g}^{-1}$ of extract for hydroxycinnamic acid derivatives, and quercetin (QE) $\mathrm{g}^{-1}$ of extract for flavonols.

\subsection{Antioxidant activity determination}

\subsubsection{Scavenging effect on DPPH radicals}

The capacity to scavenge the free radical 2,2-diphenyl-1-picrylhydrazyl (DPPH) was monitored according to the method of Hatano et al. (1988). The extract solution $(0.3 \mathrm{~mL})$ was mixed with $2.7 \mathrm{~mL}$ of a methanol solution containing DPPH radicals $\left(6 \times 10^{-5} \mathrm{~mol} \mathrm{~L}^{-1}\right)$. The mixture was shaken vigorously and left to stand for $60 \mathrm{~min}$ at room temperature in the dark (until stable absorbance values were obtained). The reduction of the DPPH radical was measured by continuous monitoring of the absorption decrease at $517 \mathrm{~nm}$ (Genesys 10UV, Thermo Electron Corporation). DPPH scavenging effect was calculated as the percentage of $\mathrm{DPPH}$ discoloration using the following equation: \% scavenging effect $=[(\mathrm{ADPPH}-\mathrm{AS}) / \mathrm{ADPPH}] \times 100$, where AS is the absorbance of the solution when the sample extract has been added, and ADPPH is the absorbance of the DPPH solution. The extract concentration providing $50 \%$ inhibition $\left(\mathrm{EC}_{50}\right.$ ) was calculated from the graph of scavenging effect percentage against extract concentration in the solution. Trolox (6-hydroxy-2,5,7,8-tetramethylchroman-2-carboxylic acid) was used as a reference at concentrations ranging from $0.0025-0.25 \mathrm{mg} \mathrm{mL}^{-1}$.

\subsubsection{Scavenging effect on ABTS radicals}

The ABTS method was applied according to that described by Karaçelil et al. (2015), based on the capacity of a sample to inhibit the ABTS radical. The ABTS radical was generated by chemical reaction with potassium persulfate $\left(\mathrm{K}_{2} \mathrm{~S}_{2} \mathrm{O}_{8}\right)$. To $25 \mathrm{~mL}$ of ABTS $\left(7 \mathrm{mmol} \mathrm{L}^{-1}\right)$ were added $440 \mathrm{~mL}$ of $\mathrm{K}_{2} \mathrm{~S}_{2} \mathrm{O}_{8}\left(140 \mathrm{mmol} \mathrm{L}^{-1}\right)$, being the solution kept in darkness during $12-16 \mathrm{~h}$ at room temperature in order to form the radical. An accurate volume of the previous solution was diluted in ethanol until an absorbance of $0.70 \pm 0.02$ at $\lambda=734 \mathrm{~nm}$ (Genesys 10 UV, Thermo Electron Corporation). Once the radical was formed $2 \mathrm{~mL}$ of ABTS radical solution were mixed with $100 \mu \mathrm{L}$ of aqueous extract of grapevine leaf at different concentrations $\left(0.01-2 \mathrm{mg} \mathrm{mL}^{-1}\right)$ and the absorbance measured at $\lambda=734 \mathrm{~nm}$. The ABTS scavenging effect and $\mathrm{EC}_{50}$ values were calculated according to the previously mentioned for the DPPH method. Trolox (6-hydroxy-2,5,7,8-tetramethylchroman-2carboxylic acid) was used as a reference at concentrations ranging from $0.0025-0.25 \mathrm{mg} \mathrm{mL}^{-1}$.

\subsubsection{Reducing power}

The reducing power was determined according to a described procedure (Berker et al., 2007). The extract solution ( $1 \mathrm{~mL}$ from 0.1 to $2 \mathrm{mg} \mathrm{mL}^{-1}$ ) was mixed with $2.5 \mathrm{~mL}$ of $200 \mathrm{mmol} \mathrm{L}^{-1}$ sodium phosphate buffer $(\mathrm{pH} 6.6)$ and $2.5 \mathrm{~mL}$ of $1 \%$ potassium ferricyanide. The mixture was incubated at $50{ }^{\circ} \mathrm{C}$ for $20 \mathrm{~min}$. After cooling, $2.5 \mathrm{~mL}$ of $10 \%$ trichloroacetic acid $(\mathrm{w} / \mathrm{v})$ were added and mixture was centrifuged at $1000 \mathrm{rpm}$ for $8 \mathrm{~min}$ (Centorion K24OR-2003 refrigerated centrifuge). The upper layer $(2.5 \mathrm{~mL})$ was mixed with $2.5 \mathrm{~mL}$ of deionized water and $0.5 \mathrm{~mL}$ of $0.1 \%$ ferric chloride, and the absorbance was measured spectrophotometrically at $700 \mathrm{~nm}$ (higher absorbance readings indicate higher reducing power). Extract concentration providing 0.5 of absorbance $\left(\mathrm{EC}_{50}\right)$ was calculated from the graph of absorbance at $700 \mathrm{~nm}$ (Genesys 10UV, Thermo Electron Corporation) against extract concentration in the solution. Trolox (6-hydroxy-2,5,7,8-tetramethylchroman-2-carboxylic acid) was used as a reference at concentrations ranging from $0.0025-0.25 \mathrm{mg} \mathrm{mL}^{-1}$.

\subsection{Statistical analysis}

\subsubsection{Analysis of variance}

The statistical analysis was carried out using Statgraphics Centurión XVI software. The mean and standard deviation were calculated using MS Excel software. When analyzing the physicochemical properties and antioxidant activity data, the normality and homogeneity of variance were always checked by the Shapiro-Wilk and Levene Tests, respectively. When both conditions failed the nonparametric Kruskal-Wallis test was applied, followed by multiple comparison of order means. On the contrary, when normality and homogeneity of variances were observed, an ANOVA followed by Tukey post-hoc test was used. All statistical tests were performed at a 5\% significance level. In addition, linear regression analysis was applied to detect the existence of significant relationships between severities irrigation and the antioxidant activity.

\subsubsection{Principal component analysis}

Principal components analysis (PCA) was applied for reducing the number of variables in the antioxidant activity and phytochemicals composition of grapevine leaves to a smaller number of new derived variables (principal component or factors) that adequately summarize the original information. Overall 7 variables corresponding to the extraction yield, antioxidant activity, and phenolic composition of the grapevine leaf with different irrigation treatment and collected period were used in PCA. PCA was performed by using SPSS software, version 22.0 (IBM Corporation, New York, U.S.A.).

\section{Results and discussion}

\subsection{Phytochemical composition affected by deficit irrigation and sampling period}

In the present work the total phenols content, hydroxycinnamic acids derivatives, and flavonols were studied in the grapevine leaves of cv. Touriga Nacional under deficit irrigation at different phenological stages of grapes, namely, veraison, maturation, and grape harvest. The results obtained are reported in Fig. 2. The irrigation clearly reduced the total phenols content in grapevine leaves at all phenological stages studied (Fig. 2). Veraison was the most affected phenological stage. For instance, compared to that of the control treatment (NI), the total phenol content was reduced by $19 \%$ in RDI20 (from $189 \mathrm{mg} \mathrm{GAE} \mathrm{g}^{-1}$ to $153 \mathrm{mg} \mathrm{GAE}^{-1}$ ), 28\% in RDI40 (136 $\mathrm{mg} \mathrm{GAE}^{-1}$ ), and 33\% in RDI60 (127 $\mathrm{mg} \mathrm{GAE}^{-1}$ ) (Fig. 2). In the maturation sampling, the following total phenols content decreases were reported relative to that of the control treatment: $13 \%$ in RDI20 (143 $\mathrm{mg} \mathrm{GAE} \mathrm{g}^{-1}$ ); and $8 \%$ and $9 \%$ in RDI40 and RDI60, respectively (151 mg GAE ${ }^{-1}$ and $149 \mathrm{mg} \mathrm{GAE} \mathrm{g}^{-1}$ ). Grapevines leaves at harvest sampling also exhibited a severe reduction in the total phenols content: $5 \%$ in RDI20 (130 $\mathrm{mg} \mathrm{GAE}^{-1}$ ); $12 \%$ in RDI40 (120 mg GAE g ${ }^{-1}$ ); and $20 \%$ in RDI60 (109 mg GAE g ${ }^{-1}$ ) (Fig. 2). Therefore, independently of the sampling period, irrigation reduces the amounts of total phenols content in grapevine leaves. Similar results were observed for hydroxycinnamic acids derivatives and flavonols. In the case of hydroxycinnamic acid derivatives, the reduction was less pronounced. In veraison sampling, the content ranged from $45 \mathrm{mg} \mathrm{CAE} \mathrm{g}^{-1}$ (RDI60) to $60 \mathrm{mg} \mathrm{CAE}^{-1}$ (NI); in the maturation sampling, the content ranged from $47 \mathrm{mg} \mathrm{CAE}^{-1}$ (RDI20 and RDI60) to $51 \mathrm{mg} \mathrm{CAE} \mathrm{g}^{-1}(\mathrm{NI})$; and in the harvest sampling, it varied between $37 \mathrm{mg} \mathrm{CAE} \mathrm{g}^{-1}$ (RDI60) and $44 \mathrm{mg} \mathrm{CAE} \mathrm{g}^{-1}$ (RDI20) (Fig. 2).

Regarding the flavonols content, a severe decrease was observed, mainly in conjunction with irrigation and the sampling time. Comparing the samples from veraison NI with those of harvest at 
A
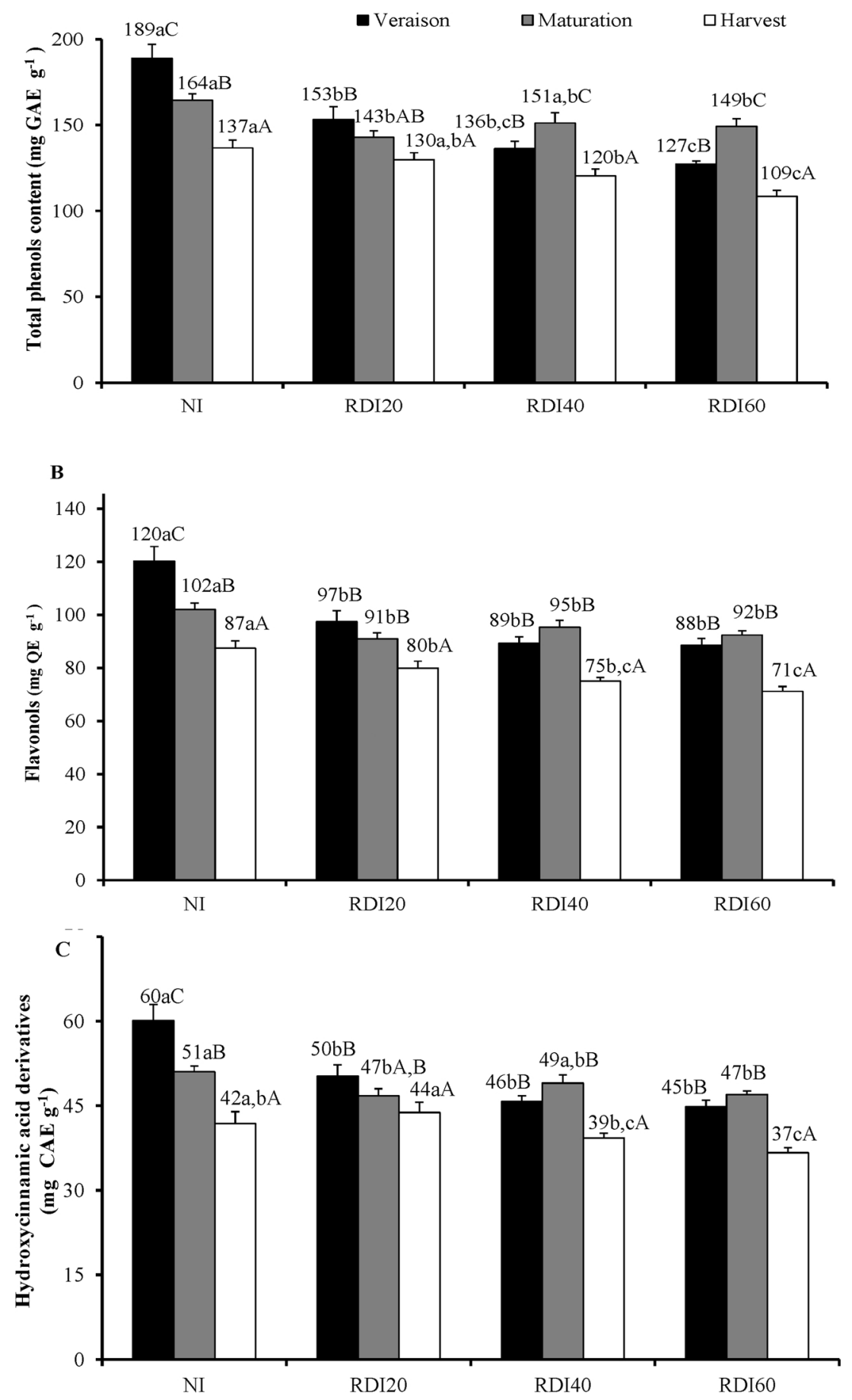

Fig. 2. (A) Total phenols content (mg GAE g-1), (B) flavonols (mg QE g-1) and (C) hydroxycinnamic acid derivatives (mg CAE g-1) in the aqueous extracts of grapevine leaf. Mean values with different lowercase letters differ significantly $(\mathrm{p} \leq 0.05)$, for the irrigation treatments studied within the same phenological stage. Mean values with different capital letters differ significantly ( $\mathrm{p} \leq 0.05$ ) for the phenological stages studied within the same irrigation treatment. NI, RDI20, RDI40, RDI60: treatments are those explained in the Material and Methods section.

RDI60, the reduction in flavonols was approximately $41 \%$ (Fig. 2).

Our results for the non-irrigated grapevines from cv. Touriga Nacional are within the range demonstrated by Lima et al. (2016) and Fernandes et al. (2013) for the same variety and within the range of other international varieties (Andelković et al., 2015; Farhadi et al., 2016; Monagas et al., 2006). Nevertheless, our results are contrary to those presented by Katalinic et al. (2011):these authors reported an accumulation of phenolic compounds over time (from May to September) but with low amounts (maximum of $47 \mathrm{mg} \mathrm{mL}^{-1}$ ) compared to our results.

The decrease in the phenolic compound content in our study may be related to the inhibition of some enzymes involved in the metabolic pathways that lead to the formation of different phenolic groups. The possible factor responsible for this inhibition is irrigation. For instance, the formation of hydroxycinnamic acids is influenced by the activity of Ł-phenylalanine ammonia-lyase (PAL) (Zhang and Liu, 2015). PAL catalyzes the reductive deamination of $\mathrm{e-phenylalanine} \mathrm{to} \mathrm{form} \mathrm{trans-}$ cinnamic acid, which is the first step for the formation of 
Table 2

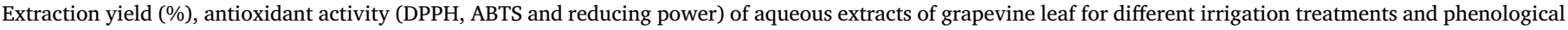
stages $(\mathrm{n}=4$; mean \pm standard deviation).

\begin{tabular}{|c|c|c|c|c|c|}
\hline Treatments & $\begin{array}{l}\text { Phenological } \\
\text { stage }\end{array}$ & $\begin{array}{l}\text { Extraction yield } \\
(\%)\end{array}$ & $\begin{array}{l}\text { DPPH } \\
\left(\mathrm{mg} \mathrm{mL}^{-1}\right)^{1}\end{array}$ & $\begin{array}{l}\text { ABTS } \\
\left(\mathrm{mg} \mathrm{mL}^{-1}\right)^{1}\end{array}$ & $\begin{array}{l}\text { Reducing power } \\
\left(\mathrm{mg} \mathrm{mL} L^{-1}\right)^{2}\end{array}$ \\
\hline \multirow[t]{3}{*}{ NI } & Veraison & $21.7 \pm 2.0^{\mathrm{bA}}$ & $0.055 \pm 0.007^{\mathrm{a}, \mathrm{bA}}$ & $0.271 \pm 0.023^{\mathrm{aB}}$ & $0.397 \pm 0.056^{\mathrm{aA}}$ \\
\hline & Maturation & $22.3 \pm 1.4^{\mathrm{cA}}$ & $0.085 \pm 0.010^{\mathrm{aB}}$ & $0.210 \pm 0.019^{\mathrm{bA}}$ & $0.419 \pm 0.063^{\mathrm{aA}}$ \\
\hline & Harvest & $19.4 \pm 1.4^{\mathrm{aA}}$ & $0.092 \pm 0.010^{\mathrm{aB}}$ & $0.339 \pm 0.033^{\mathrm{aC}}$ & $0.440 \pm 0.054^{\mathrm{aA}}$ \\
\hline \multirow[t]{3}{*}{ RDI20 } & Veraison & $20.3 \pm 1.7^{\mathrm{a}, \mathrm{bAB}}$ & $0.074 \pm 0.020^{\mathrm{bA}}$ & $0.279 \pm 0.025^{\mathrm{aB}}$ & $0.462 \pm 0.065^{\mathrm{a}, \mathrm{bA}}$ \\
\hline & Maturation & $19.7 \pm 1.1^{\mathrm{a}, \mathrm{bA}}$ & $0.112 \pm 0.013^{\mathrm{bB}}$ & $0.185 \pm 0.008^{\mathrm{aA}}$ & $0.549 \pm 0.070^{\mathrm{bB}}$ \\
\hline & Harvest & $22.4 \pm 1.3^{\mathrm{a}, \mathrm{bB}}$ & $0.110 \pm 0.014^{\mathrm{a}, \mathrm{bB}}$ & $0.468 \pm 0.086^{b c}$ & $0.510 \pm 0.067^{\mathrm{bAB}}$ \\
\hline \multirow[t]{3}{*}{ RDI40 } & Veraison & $17.8 \pm 1.6^{\mathrm{aA}}$ & $0.047 \pm 0.002^{\mathrm{aA}}$ & $0.330 \pm 0.036^{\mathrm{bA}}$ & $0.479 \pm 0.099^{\mathrm{bA}}$ \\
\hline & Maturation & $17.7 \pm 1.8^{\mathrm{aA}}$ & $0.113 \pm 0.008^{\mathrm{bB}}$ & $0.343 \pm 0.027^{\mathrm{cA}}$ & $0.458 \pm 0.045^{\mathrm{aA}}$ \\
\hline & Harvest & $20.5 \pm 2.6^{\mathrm{a}, \mathrm{bA}}$ & $0.133 \pm 0.044^{\mathrm{bB}}$ & $0.450 \pm 0.064^{\mathrm{bB}}$ & $0.573 \pm 0.080^{\mathrm{bB}}$ \\
\hline \multirow[t]{3}{*}{ RDI60 } & Veraison & $18.6 \pm 2.3^{\mathrm{a}, \mathrm{bA}}$ & $0.094 \pm 0.031 \mathrm{cA}$ & $0.333 \pm 0.049^{\mathrm{bA}}$ & $0.488 \pm 0.057^{\mathrm{bA}}$ \\
\hline & Maturation & $21.7 \pm 1.6^{\mathrm{c}, \mathrm{bA}, \mathrm{B}}$ & $0.119 \pm 0.020^{\mathrm{bA}}$ & $0.404 \pm 0.033^{\mathrm{dB}}$ & $0.562 \pm 0.049^{\mathrm{bB}}$ \\
\hline & Harvest & $22.9 \pm 1.4^{\mathrm{bB}}$ & $0.187 \pm 0.022^{\mathrm{cB}}$ & $0.507 \pm 0.070^{b C}$ & $0.580 \pm 0.068^{\text {вв }}$ \\
\hline Trolox & - & - & $0.037 \pm 0.000$ & $0.068 \pm 0.001$ & $0.159 \pm 0.001$ \\
\hline
\end{tabular}

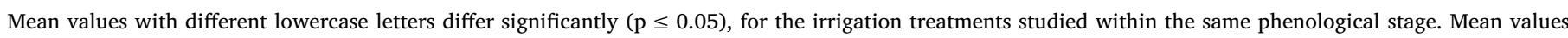
with different capital letters differ significantly $(\mathrm{p} \leq 0.05)$ for the phenological stages studied within the same irrigation treatment.

NI, RDI20, RDI40, RDI60: treatments are those explained in the Material and Methods section.

${ }^{1} \mathrm{EC}_{50}\left(\mathrm{mg} \mathrm{mL}^{-1}\right)$ : effective concentration at which $50 \%$ of the DPPH or ABTS radicals are scavenged.

${ }^{2} \mathrm{EC}_{50}\left(\mathrm{mg} \mathrm{mL}^{-1}\right)$ : effective concentration at which the absorbance is 0.5 .

Table 3

Correlation between irrigation treatments (NI, RDI20, RDI40, RDI60) for different collected time and respective antioxidant activity and phytochemical composition.

\begin{tabular}{|c|c|c|c|c|c|c|c|c|c|}
\hline & \multicolumn{3}{|l|}{ Veraison } & \multicolumn{3}{|l|}{ Maturation } & \multicolumn{3}{|l|}{ Harvest } \\
\hline & Equation & $\mathrm{R}^{2}$ & $\mathrm{P}$ & Equation & $\mathrm{R}^{2}$ & $\mathrm{P}$ & Equation & $\mathrm{R}^{2}$ & $\mathrm{P}$ \\
\hline \multicolumn{10}{|l|}{ Antioxidant activity } \\
\hline $\mathrm{EC}_{50} \mathrm{ABTS}$ & $y=0.001 x+0.267$ & 0.375 & **** & $y=0.004 x+0.174$ & 0.780 & $* * *$ & $y=0.002 x+0.369$ & 0.388 & $* * *$ \\
\hline $\mathrm{EC}_{50}$ Reducing power & $y=0.001 x+0.413$ & 0.183 & * & $y=0.002 x+0.445$ & 0.210 & $* *$ & $y=0.002 x+0.454$ & 0.402 & $* * *$ \\
\hline $\begin{array}{l}\text { Phytochemical composition } \\
\text { Total phenols content }\end{array}$ & & & & & & & & & \\
\hline $\begin{array}{l}\text { Total phenols content } \\
\text { Flavonols }\end{array}$ & $\begin{array}{l}y=-1.005 x+181.556 \\
y=-0.516 x+114.33\end{array}$ & 0.625 & $* * *$ & $y=-0.185 x+157.436$ & 0.080 & n.s. & $y=-0.470 x+137.907$ & 0.488 & $* * *$ \\
\hline
\end{tabular}

n.s. - not significant; ${ }^{*} \mathrm{P} \leq 0.05-$ significant correlation; ${ }^{* *} \mathrm{P} \leq 0.01-$ very significant correlation; ${ }^{* * *} \mathrm{P} \leq 0.001-$ extremely significant correlation.

phenylpropanoid compounds. Therefore, a higher accumulation of hydroxycinnamic acids in stressed vineyards is expected, as seen in our study.

Another important enzyme is chalcone synthase (CHS), which is responsible for the biosynthesis of flavonoids (Sgarbi et al., 2003). This enzyme is responsible for the first steps of flavonoids formation (Winkel-Shirley, 2002), and in the grapevines leaves of cv. Touriga Nacional, $67 \%$ of the phenolic compounds are flavonoids, namely, quercetin-3-O-glucoside and quercetin-3-O-galactoside (Fernandes et al., 2013). Irrigation reduces the enzymatic activity of CHS, according to Castellarin et al. (2007), because in water-stressed vines, it was observed that genes encoding this enzyme were up regulated, therefore yielding flavonoids.

Photosynthesis is the main function of the leaves in the plant. One of the main mechanisms involved in the process of photosynthesis is the regulation of the stomatal opening. Stomata are structures located on the surface of the leaves that regulate gas exchange and transpiration in the plant. When water stress occurs in the vineyard, there are different responses of the plant to adapt and survive. One of these mechanisms of resistance at the physiological level is the closing of stomata to reduce water losses through transpiration (Taiz and Zeiger, 2006). This response is mediated by abscisic acid (ABA) (Zhang and Outlaw, 2001). $\mathrm{ABA}$ is a hormone that is synthesized in the roots. When there is a stress situation caused by abiotic agents (drought, frost, among others) or by biotic agents (pests or diseases), the levels of abscisic acid (ABA) are increased in vegetative tissues (Sivaci et al., 2007). The synthesis of $\mathrm{ABA}$ in the roots increases in response to a water shortage in the soil.

The ABA is transported to mesophyll cells through the xylem, inducing stomata closure. As, we can see in the climatic conditions represented in Fig. 1, during the period in which the leaves were collected, the rainfall was residual, and the solar radiation reached maximum levels, producing a great hydric stress in the vines. This stress was possibly manifested by a greater synthesis of $A B A$, which acts in the closure of stomata in the hours of greater insolation. With the increase in the concentration of $\mathrm{ABA}$ in the plant there, was an increase in the synthesis of phenolic compounds and antioxidant activity, as demonstrated by Xi et al. (2012). Therefore, due to irrigation, the water stress was reduced, and consequently, the amounts of total phenols, flavonols and hydroxycinnamic acid derivatives were also reduced.

The reduction in the total phenols content and the flavonols and hydroxycinnamic acids derivative levels was also corroborated by the correlations established with the different levels of irrigation (NI, RDI20, RDI40, and RDI60) (Table 3). From the results obtained in the regression analysis, it was possible to verify that the correlations obtained were inversely proportional, with a negative slope. This information is important, since lower irrigation regimes are associated higher concentrations of phytochemicals, namely, total phenols, hydroxycinnamic acids derivatives, and flavonols. This information was verified independently of the harvest moment of the leaves.

Therefore, in general, vines responding stress increase the synthesis of phenolic compounds, namely, flavonols and hydroxycinnamic acid derivatives, since these compounds are involved in protective mechanisms against oxidative stress (Dixon and Paiva, 1995; Grace, 2005). Accordingly, when irrigation water increases, low levels of hydric stress are observed, negatively affecting the total phenols content. This result may have repercussions in the bioactive properties of grapevine leaves, 


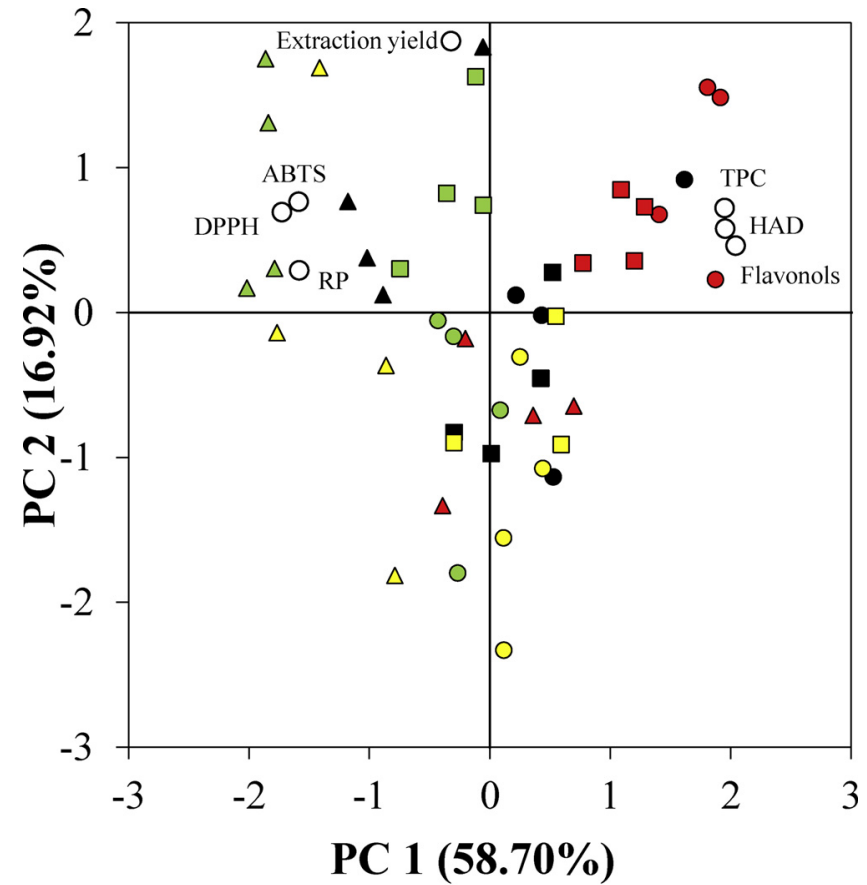

$\begin{array}{lcccc} & \text { NI } & \text { RDI20 } & \text { RDI40 } & \text { RDI60 } \\ \text { Veraison } & \bigcirc & \bullet & \bigcirc & 0 \\ \text { Maturation } & \square & \square & \square & \square \\ \text { Harvest } & \Delta & \Delta & \Delta & \Delta\end{array}$

Fig. 3. Principal component analysis obtained from grapevine leave with different irrigation treatments and phenological stages by using the data relative to the extraction yield, phenolic composition [TPC - total phenols content; HAD - hydroxycinnamic acid derivatives; and flavonols), and antioxidant activity $\left(\mathrm{EC}_{50}\right.$ values of DPPH, ABTS and reducing power (RP)]. The principal components explain $75.62 \%$ of the total variance.

since phenolic compounds are recognized compounds with an array of important biological functions and properties (Caleja et al., 2017; Dani et al., 2010).

\subsection{Antioxidant properties affected by deficit irrigation and sampling period}

The antioxidant properties of the grapevine leaves, namely, antiradical activity (DDPH and ABTS) and the reducing power were assessed, and the obtained results are reported in Table 2. Independently of the method assessed and sampling period, the irrigation affected the antioxidant properties of grapevine leaves from cv. Touriga Nacional, as we observed a generalized reduction in the antioxidant properties. For instance, at veraison phenological stage, the $\mathrm{EC}_{50}$ values ranged from $0.047 \mathrm{mg} \mathrm{mL}^{-1}$ (RDI40) to $0.094 \mathrm{mg} \mathrm{mL}^{-1}$ (RDI60). During maturation, the DPPH values ranged from $0.085 \mathrm{mg} \mathrm{mL}^{-1}$ (NI) to $0.119 \mathrm{mg}$ $\mathrm{mL}^{-1}$ (RDI60). For harvest sampling, the loss of antioxidant activity was more linked with $\mathrm{EC}_{50}$ values varying between $0.092 \mathrm{mg} \mathrm{mL}^{-1}$ (NI) and $0.187 \mathrm{mg} \mathrm{mL}^{-1}$ (RDI60).

Regarding the ABTS assay, the same trend was observed, i.e., decreased antioxidant properties associated with irrigation and sampling period. In veraison, the $\mathrm{EC}_{50}$ values for ABTS varied between $0.271 \mathrm{mg} \mathrm{mL}^{-1}$ (NI) and $0.333 \mathrm{mg} \mathrm{mL}^{-1}$ (RDI60). In the maturation, $\mathrm{RDI} 20$ showed the lowest $\mathrm{EC}_{50}$ values, with $0.185 \mathrm{mg} \mathrm{mL}^{-1}$, and RDI60 showed the highest value, with $0.507 \mathrm{mg} \mathrm{mL}^{-1}$ (Table 2). Again, the leaves from the harvest sampling showed the most decreased $\mathrm{EC}_{50}$ values, which varied between $0.339 \mathrm{mg} \mathrm{mL}^{-1}$ (NI) and $0.507 \mathrm{mg} \mathrm{mL}^{-1}$ (RDI60).

The capacity of the extracts from grapevine leaves to reduce the
$\mathrm{Fe}^{3+}$ /ferricyanide complex to the ferrous form was also negatively affected. The joint action of irrigation and sampling period caused the greatest loss in the reducing capacity of grapevine leaf extracts. For instance, in the sampling harvest at $\mathrm{NI}$, the extracts reported an $\mathrm{EC}_{50}$ value of $0.440 \mathrm{mg} \mathrm{mL}^{-1}$, while with the treatment RDI60, the value increased to $0.580 \mathrm{mg} \mathrm{mL}^{-1}$ (Table 2). At veraison, the $\mathrm{EC}_{50}$ values increased from $0.397 \mathrm{mg} \mathrm{mL}^{-1}$ at NI to $0.488 \mathrm{mg} \mathrm{mL}^{-1}$ at RDI60. At maturation sampling, the $\mathrm{EC}_{50}$ values ranged from $0.419 \mathrm{mg} \mathrm{mL}^{-1}(\mathrm{NI})$ to $0.562 \mathrm{mg} \mathrm{mL}^{-1}$ (RDI60).

The results obtained in the antioxidant assays are in accordance with those obtained by Lima et al. (2016) and Fernandes et al. (2013). With the present study, we can conclude with the information found that the joint action of irrigation and sampling period reduced the antioxidant properties of the grapevine leaf extracts. This result was clearly related to the loss of total phenolic compounds in the leaves, as discussed earlier, due to the interference in the enzymatic pathways that lead to the formation of flavonoids and phenylpropanoid compounds. The same was observed in grapes with irrigation and sampling period, as described by Garrido et al. (2016) and Conesa et al. (2016).

This aspect was corroborated by our data when we correlated the antioxidant activity with the total phenol content. In Table 3, a regression analysis was established between the different irrigation regimes (NI, RDI20, RDI40 and RDI60) and the $\mathrm{EC}_{50}$ values from the antioxidant assays. The correlations obtained were clear and directly proportional, with a positive slope. Therefore, the more water provided to the vineyard, the higher the $\mathrm{EC}_{50}$ values obtained in the antioxidant assays were. However, a high $\mathrm{EC}_{50}$ value was ascribed with lower antioxidant activity, since these two aspects are inversely related.

By applying the obtained data in a PCA, we also corroborated this relation (Fig. 3). The first and second principal components (PC1 and PC2) explained $75.62 \%$ of the total variance. The variables TPC (total phenols content), HAD (hydroxycinnamic acid derivatives), and flavonols are represented in the positive regions of both PCs. These variables are related mainly to samples with higher amounts of these phytochemicals, mainly those extracts without irrigation and veraison. In the opposite region (the positive region of PC2 and the negative region of PC1) are reported those extracts with lower amounts of phytochemicals, mainly those from the harvest sampling treatment RDI60. These extracts are also characterized by higher $\mathrm{EC}_{50}$ values for DPPH, ABTS, and the reducing power methods, as inferred from the resulting PCA (Fig. 3). With PCA, it is also possible to verify that the joint action of irrigation and sampling period was critical for influencing the phytochemical composition and antioxidant properties of the extracts from grapevine leaves.

\section{Conclusions}

The results obtained in the present study allowed us to conclude that irrigation and sampling period drastically affect the phytochemical composition and antioxidant activity of grapevine leaves. The joint action of both variables (the amount of water and the sampling period) can lead to a loss of approximately $42 \%$ of total phenols. The antioxidant properties were affected as well. Higher losses were reported in the period relative to the grape harvest. It was also concluded that the loss of antioxidant properties was correlated with the decreased phenolic content of the grapevine leaves. Therefore, we recommend that grapevine leaves should be collected pre-veraison or at veraison in order to obtain extracts that have a high content of phytochemicals and bioactive properties. In this sense, we can obtain a byproduct with good amounts of phytochemicals with bioactive properties, and, at the same time, we can improve the berry quality to obtain grapes for a better wine or for fresh consumption.

\section{Acknowledgements}

The authors wish to thank the financial support provided to David 
Barreales (research grant SFRH/BD/139393/2018) by the Portuguese Foundation for Science and Technology (FCT, Portugal) and to the financial support provided to the DOUROZONE project - Risco de exposição ao ozono para a vinha Duriense em clima atual e futuro (PTDC/AAG-MAA/3335/2014; POCI-01-0145-FEDER-016778) funded by the FCT/MCTES (PIDDAC) and co-funded by the Fundo Europeu de Desenvolvimento Regional (FEDER) through COMPETE - Programa Operacional Fatores de Competitividade (POFC).

The authors thank to the Soc. Clemente Menéres Lda. (Menéres Family Estate) for allowing this research activity in its vineyard.

\section{References}

Allen, R.G., Pereira, L.S., Raes, D., Smith, M., 1998. Crop Evapotranspiration. Guidelines for Computing Crop Water Requirements. FAO Irrigation and Drainage, Rome Paper 56.

Andelković, M., Radovanović, B., Andelković, A.M., Radovanović, V., 2015. Phenolic compounds and bioactivity of healthy and infected grapevine leaf extracts from red varieties Merlot and Vranac (Vitis vinifera L.). Plant Foods Hum. Nutr. 70, 317-323. https://doi.org/10.1007/s11130-015-0496-3.

Berker, K., Güçlü, K., Tor, I., Apak, R., 2007. Comparative evaluation of Fe (III) reducing power-based antioxidant capacity assays in the presence of phenanthroline, bathophenanthroline, tripyridyltriazine (FRAP) and ferricyanide reagents. Talanta 72 , 1157-1165. https://doi.org/10.1016/j.talanta.2007.01.019.

Boulanouar, B., Abdelaziz, G., Aazza, S., Gago, C., Miguel, M.G., 2013. Antioxidant activities of eight Algerian plant extracts and two essential oils. Ind. Crops Prod. 46, 85-96. https://doi.org/10.1016/j.indcrop.2013.01.020.

Bubola, M., Sivilotti, P., Janjanin, D., Poni, S., 2017. Early leaf removal has larger effect than cluster thinning on cv. Teran grape phenolic composition. Am. J. Enol. Vitic. https://doi.org/10.5344/ajev.2016.16071.

Caleja, C., Ribeiro, A., Barreiro, M.F., Ferreira, I.C.F.R., 2017. Phenolic compounds as nutraceuticals or functional food ingredients. Curr. Pharm. Des. 23, 2787-2806. https://doi.org/10.2174/1381612822666161227153906.

Castellarin, S.D., Pfeiffer, A., Sivilotti, P., Degan, M., Peterlunger, E., Di Gaspero, G., 2007. Transcriptional regulation of anthocyanin biosynthesis in ripening fruits of grapevine under seasonal water deficit. Plant Cell Environ. 30, 1381-1399. https:// doi.org/10.1111/j.1365-3040.2007.01716.x.

Conesa, M.R., Falagán, N., De La Rosa, J.M., Aguayo, E., Domingo, R., Pastor, A.P., 2016. Post-veraison deficit irrigation regimes enhance berry coloration and health-promoting bioactive compounds in 'Crimson Seedless' table grapes. Agric. Water Manag. 163, 9-18. https://doi.org/10.1016/j.agwat.2015.08.026.

Dani, C., Oliboni, L.S., Agostini, F., Funchal, C., Serafini, L., Henriques, J.A., Salvador, M., 2010. Phenolic contente of grapevine leaves (Vitis labrusca var. Bordo) and its neuroprotective effect against peroxide damage. Toxicol. In Vitro 24, 148-153. https:// doi.org/10.1016/j.tiv.2009.08.006.

De la Hera, M.L., Martínez-Cutillas, A., López-Roca, J.M., Gómez-Plaza, E., 2004. Effects of moderate irrigation on vegetative growth and reproductive parameters of Monastrell vines grown in semiarid conditions. Span. J. Agric. Res. 2, 273-281. https://doi.org/10.5424/sjar/2004022-81.

Delìorman Orhan, D., Orhan, N., Özçelik, B., Ergun, F., 2009. Biological activities of Vitis vinifera L. leaves. Turk. J. Biol. 33, 341-348. https://doi.org/10.3906/biy-0806-17.

Devi, S., Singh, R., 2017. Evaluation of antioxidant and anti-hypercholesterolemic potential of Vitis vinifera leaves. Food Sci. Hum. Wellness 6, 131-136. https://doi.org/ 10.1016/j.fshw.2017.07.002.

Dixon, R.A., Paiva, N.L., 1995. Stress-induced phenylpropanoid metabolism. Plant Cell 7, 1085-1097. https://doi.org/10.1105/tpc.7.7.1085.

Doshi, P., Adsule, P., Banerjee, K., 2006. Phenolic composition and antioxidant activity in grapevine parts and berries (Vitis vinifera L.) cv Kishmish Chornyi (Sharad Seedless) during maturation. Int. J. Food Sci. Technol. 41, 1-9. https://doi.org/10.1111/j. 1365-2621.2006.01214.x.

Dry, P.R., Loveys, B.R., McCarthy, M.G., Stoll, M., 2001. Strategic irrigation management in Australian vineyards. J. Int. Sci. Vigne Vin. 35, 129-139. https://doi.org/10. 20870/oeno-one.2001.35.3.1699.

Farhadi, K., Esmaeilzadeh, F., Hatami, M., Forough, M., Molaie, R., 2016. Determination of phenolic compounds content and antioxidant activity in skin, pulp, seed, cane and leaf of five native grape cultivars in West Azerbaijan province. Iran. Food Chem. 199, 847-855. https://doi.org/10.1016/j.foodchem.2015.12.083.

Fernandes, F., Ramalhosa, E., Pires, P., Verdial, J., Valentão, P., Andrade, P., Pereira, J.A., 2013. Vitis vinifera leaves towards bioactivity. Ind. Crops Prod. 43, 434-440. https:// doi.org/10.1016/j.indcrop.2012.07.031.

Garrido, I., Uriarte, D., Hernández, M., Llerena, J.L., Valdés, M.E., Espinosa, F., 2016. The evolution of total phenolic compounds and antioxidant activities during ripening of grapes (Vitis vinifera L., cv. Tempranillo) grown in semiarid region: effects of cluster thinning and water deficit. Int. J. Mol. Sci. 17 (11), 1923. https://doi.org/10.3390/ ijms17111923.

Grace, S.C., 2005. Phenolics as antioxidants. In: Smirnoff, N., Grace, S.C. (Eds.), Antioxidants and Reactive Oxygen Species in Plants. Blackwell, Oxford, UK, pp. 141-168. https://doi.org/10.1002/9780470988565. ch6.

Hamman, R.A., Dami, I.E., 2000. Effects of irrigation on wine, grape growth and fruit quality. HortTechnology 10, 162-168.

Harb, J., Alseekh, S., Tohge, T., Fernie, A.R., 2015. Profiling of primary metabolites and flavonols in leaves of two table grape varieties collected from semiarid and temperate regions. Phytochemistry 117, 444-455. https://doi.org/10.1016/j.phytochem.2015. 07.013.

Hatano, T., Kagawa, H., Yasuhara, T., Okuda, T., 1988. Two new flavonoids and other constituents in licorice root: their relative astringency as scavenging effects. Chem. Pharm. Bull. 36, 2090-2097. https://doi.org/10.1248/cpb.36.2090.

Hebash, K.A.H., Fadel, H.M., Soliman, M.M.A., 1991. Volatile components of grape leaves. J. Int. AIDS Soc. 4, 26-28. https://doi.org/10.1080/14786419.2014.957697.

Jones, G.V., 2013. Uma Avaliação do Clima para a Região Demarcada do Douro: Uma análise das condições climáticas do passado, presente e futuro para a produção de vinho. Livro editado por ADVID - Associação para o Desenvolvimento da Viticultura Duriense.

Karaçelil, A.A., Küçük, M., Iskefiyeli, Z., Aydemir, S., De Smet, S., Miserez, B., Sandra, P., 2015. Antioxidant components of Viburnum opulus L. determined by on-line HPLCUV-ABTS radical scavenging and LC-UV-ESI-MS methods. Food Chem. 175, 106-114. https://doi.org/10.1016/j.foodchem.2014.11.085.

Katalinic, V., Mozina, S.S., Generalic, I., Skroza, D., Ljubenkov, I., Klancnik, A., 2011. Phenolic profile, antioxidant capacity, and antimicrobial activity of leaf extracts from six Vitis vinifera L. varieties. Inter J Food Prop 16, 45-60. https://doi.org/10.1080/ 10942912.2010 .526274$.

Köppen, W., 1923. Die Klimate der Erde. Berlin, Leipzig. https://doi.org/10.1002/qj. 49705021022.

Kriedemann, P.E., Goodwin, I., 2003. Regulated Deficit Irrigation and Partial Root-zone Drying. An Overview of Principles and Applications. Irrigation Insights Number. 4. Land and Water Australia.

Lima, A., Bento, A., Baraldi, I., Malheiro, R., 2016. Selection of grapevine leaf varieties for culinary process based on phytochemical composition and antioxidant properties. Food Chem. 212, 291-212295. https://doi.org/10.1016/j.foodchem.2016.05.177.

Lima, A., Pereira, J.A., Baraldi, I., Malheiro, R., 2017. Cooking impact in color, pigments and volatile composition of grapevine leaves (Vitis vinifera L. Var. Malvasia Fina and Touriga Franca). Food Chem. 221, 1197-1205. https://doi.org/10.1016/j.foodchem. 2016.11.039.

Lorenz, D.H., Eichhorn, K.W., Bleiholder, H., Klose, R., Meier, U., Weber, E., 1995. Phenological growth stages of the grapevine (Vitis vinifera L. Ssp. vinifera) - codes and descriptions according to the extended BBCH scale. Aust. J. Grape Wine Res. 1, 100-110. https://doi.org/10.1111/j.1755-0238.1995.tb00085.x.

Meier, U., 2001. Growth Stages of Mono-and Dicotyledonous Plants, 2nd edition. BBCH Monograph. Federal Biological Research Centre for Agriculture and Forestry, Bonn.

Monagas, M., Hernández-Ledesma, B., Gómez-Cordovés, C., Bartolomé, B., 2006. Commercial dietary ingredients from Vitis vinifera L. leaves and grape skins: antioxidant and chemical characterization. J. Agric. Food Chem. 54, 319-327. https:// doi.org/10.1021/jf051807j.

Pastore, C., Allegro, G., Valentini, G., Muzzi, E., Filippetti, I., 2017. Anthocyanin and flavonol composition response to veraison leaf removal on Cabernet Sauvignon, Nero d'Avola, Raboso Piave and Sangiovese Vitis vinifera L. cultivars. Sci. Hortic. 218, 147-155. https://doi.org/10.1016/j.scienta.2017.01.048.

Roby, G., Matthews, A., 2004. Relative proportions of seed, skin and flesh, in ripe berries from Cabernet Sauvignon grapevines grown in a vineyard either well irrigated or under water deficit. Aust. J. Grape Wine Res. 10, 74-82. https://doi.org/10.1111/j. 1755-0238.2004.tb00009.x.

Romero, P., Gil-Muñoz, R.M., del Amor, F., Valdés, E., Fernández, J.I., Martinez-Cutillas, A., 2013. Regulated Deficit Irrigation based upon optimum water status improves phenolic composition in Monastrell grapes and wines. Agric. Water Manag. 121, 85-101. https://doi.org/10.1016/j.agwat.2013.01.007.

Sendoğdu, N., Aslan, M., Deliorman Orhan, D., Ergun, F., Yesilada, E., 2006. Antidiabetic and antioxidant effects of Vitis vinifera L. leaves in streptozotocin-diabetic rats. Turk. J. Pharm. Sci. 3, 7-18.

Sgarbi, E., Fornasiero, R.B., Lins, A.P., Bonatti, P.M., 2003. Phenol metabolism in differentially affected by ozone in two cell lines from grape (Vitis vinifera L.) leaf. Plant Sci. 165, 951-957. https://doi.org/10.1016/S0168-9452(03)00219-X.

Sivaci, A., Sivaci, E.R., Sökmen, M., 2007. Changes in antioxidant activity, total phenolic and abscisic acid constituents in the aquatic plants Myriophyllum spicatum L. and Myriophyllum triphyllum Orchard exposed to cadmium. Ecotoxicology 16, 423-428. https://doi.org/10.1007/s10646-007-0145-1.

Taiz, L., Zeiger, E., 2006. Plant Physiology, 4th ed. Sinauer Associates, Sunderland, MA. https://doi.org/10.1093/aob/mcg079.

Torres, N., Goicoechea, N., Antolín, M., 2017. Influence of irrigation strategy and mycorrhizal inoculation on fruit quality in different clones of Tempranillo grown under elevated temperatures. Agric. Water Manag. https://doi.org/10.1016/j.agwat.2017. 12.004 .

Winkel-Shirley, B., 2002. Biosynthesis of flavonoids and effects of stress. Curr. Opin. Plant Biol. 5, 218-223. https://doi.org/10.1016/S1369-5266(02)00256-X.

Xi, Z.M., Meng, J.F., Huo, S.S., Luan, L.Y., Ma, L.N., Zhang, Z.W., 2012. Exogenously applied abscisic acid to Yan73 (V. vinifera) grapes enhances phenolic content and antioxidant capacity of its wine. Int. J. Food Sci. Nutr. 64. https://doi.org/10.3109/ 09637486.2012 .746291$.

Xia, E.-Q., Deng, G.-F., Guo, Y.-J., Li, H.-B., 2010. Biological activities of polyphenols from grapes. Int. J. Mol. Sci. 11, 622-646. https://dx.doi.org/10.3390\% 2Fijms11020622.

Zhang, X., Liu, C.-J., 2015. Multifaceted regulations of gateway enzyme phenylalanine ammonia-lyase in the biosynthesis of phenylpropanoids. Mol. Plant 8, 17-27. https:// doi.org/10.1016/j.molp.2014.11.001.

Zhang, S.Qy, Outlaw, W.H., 2001. Abscisic acid introduced into the transpiration stream accumulates in the guard cell apoplast and causes stomatal closure. Plant Cell Environ. 24, 1045-1054. https://doi.org/10.1046/j.1365-3040.2001.00755.x. 